\title{
About farmers' bargaining power within the new CAP
}

\author{
Beatriz Velázquez ${ }^{1 *}$, Bruno Buffaria $^{2}$ and European Commission
}

\author{
* Correspondence: \\ beatriz.velazquez@ec.europa.eu \\ ${ }^{1}$ Internal Market, Industry, \\ Competitiveness, and SMEs, \\ European Commission, Brussels, \\ Belgium \\ Full list of author information is \\ available at the end of the article
}

\begin{abstract}
This paper examines the current setting of instruments aimed at rebalancing unequal market power in the food chain. Particular attention is given to horizontal integration possibilities for farmers, and organisations of farmers, as derogations to competition policies contained in the Common Market Organisation Regulation (EU) 1308/2013 (CMO Regulation). Firstly, we propose a review of the literature that looks at the imperfect price transmission along the food chain. Secondly, we examine how CAP of instruments aimed at counterbalancing market inequalities along the chain have been functioning over time, notably if they contributed to improving efficiency, farmers' income and consumers' welfare. Thirdly, we assess the current setting of the CMO Regulation, in particular, the way derogations to the competition policy are defined (exclusions, e.g. producer's organisations). The main research question here is if the current setting does, or does not, allow attaining the objective of strengthening the bargaining power of producers, while at the same time avoiding the creation of monopoly power. Our research highlights that divergent results emerged from studies on the relation between size and profitability or efficiency, with evidence of significant economies of scale. Larger PO not only would be more profitable, but they also may offer more services to their members, especially when these services are associated with significant investment costs. In relation to policy measures aimed at improving the functioning of the food supply chain, the CMO Regulation relies on producer's organisations as the main vehicle for producer cooperation. But the new legislative setting could lead to the paradoxical consequence of impeding the functioning by challenging the existence and/or creation of POs.
\end{abstract}

Keywords: Common Agricultural Policy, Competition Law, Producer's organisations

\section{Background}

The relationship between market structure and welfare distribution between upstream and downstream sectors have been subject to careful scrutiny since 2000. In particular, the functioning of the food supply chain has merited utmost attention following increasing commodity price volatility and greater emphasis on food security issues (European Commission 2009, McCorriston 2013).

The search for balancing the bargaining power of farmers has led to specific legal solutions within the sector. Experience varied between countries although a common feature is derogations to competition policy (Nash et al. 1996; Del Cont et al. 2012, Carrau, 2012; Andries and Garcia Azcarate 2015). Moreover, in Europe the move from

(c) The Author(s). 2017 Open Access This article is distributed under the terms of the Creative Commons Attribution 4.0 International License (http://creativecommons.org/licenses/by/4.0/), which permits unrestricted use, distribution, and reproduction in any medium, provided you give appropriate credit to the original author(s) and the source, provide a link to the Creative Commons license, and indicate if changes were made. 
price to income support within the Common Agriculture Policy (CAP) has increased farmers' market exposure (Tothova Velazquez 2012; European Commission 2010). This was evident during the troublesome market situation of 2008-2009 when dairy farmers faced harsh difficulties and called for improvement in the functioning of the food chain intensified during this period. The so-called milk package, which contains provisions aiming at improving the bargaining power of farmers in the dairy sector reflects these concerns.

It is widely recognised in the literature that integration into horizontal organisations brings benefits to farmers (see Bijman J. et al. 2012). In particular, it has been demonstrated that through pooling their agricultural output, farmers may strengthen their bargaining power vis-à-vis potential buyers and input suppliers, reduce risks associated with farming activities, gain market access to particular marketing channels and benefit from economies of scale. As member of producer's organisations (POs) farmers may be able to invest collectively in assets or services requiring high fixed costs allowing them, for instance, to access new technologies and to improve efficiency and productivity, which ultimately lead to higher income (Acharya, Kinnucan, Caudill 2011; Carrau, 2014; McCorriston, 2002; Russo Goodhue Sexton, 2011, Van Heck 2014).

This paper examines the current setting of instruments aimed at rebalancing unequal market power in the food chain. Particular attention is given to horizontal integration possibilities for farmers, and organisations of farmers, like derogations to competition policies contained in the Common Market Organisation Regulation (EU) 1308/2013 (CMO Regulation). We focus on how these derogations have been defined across agricultural sectors, including the guidelines tabled by the European Commission. The ultimate objective is to assess whether the current policy framework would allow a smooth functioning of the food supply chain taking into consideration structural inequalities between actors along the chain, i.e. farmers, industry, retailers while at the same time helping producers to improve their competitiveness and achieving reasonable prices for consumers, as required by Article 39 of the Treaty on the Functioning of the EU (TFEU).

Firstly, we propose a review of the literature that looks at the imperfect price transmission along the food chain, with special attention on the economic impact of market power disparities along the food chain. Secondly, we examine how CAP of instruments aimed at counterbalancing power inequalities along the chain have been functioning over time, notably if they contributed to improving efficiency, farmers' income and consumers' welfare. Thirdly, we assess the current setting of the CMO Regulation, in particular, the way derogations to the competition policy are defined (exclusions, e.g. producer's organisations). We also refer to the way the commission intends to guide their implementation. The main research question here is if the current setting does, or does not, allow attaining the objective of strengthening the bargaining power of producers, while at the same time avoiding the creation of monopoly power.

\section{Imperfect price transmission along the food chain}

The focus of this paragraph is on the impact of market power disparities on imperfect price transmission along the food chain. It appears relevant to differentiate the variety of "power" typologies (market power, bargaining power, etc): 
- Market power (or monopoly) is the ability of a firm (or groups of firms) to raise and maintain price above the level it would prevail under competition. The exercise of market power leads to reduced output and loss of economic welfare (Khemani and Shapiro 1993).

- Bargaining power refers to "the power to obtain a concession from another party by threatening to impose a cost, or withdraw a benefit, if the party does not grant the concession." (Kirkwood 2005). The emphasis here is on a specific negotiation among certain parties, disregarding the outcome at industry level.

- Buyer power can be defined as bargaining power exerted by a buyer, for example, a processing firm with respect to farmers (Sorrentino, Russo and Cachiarelli 2016).

- Countervailing power refers to the ability of offsetting, in whole or in part, the market and/or the bargaining power of another firm (Oecd 2009).

A significant amount of research work has focused on methods for understanding price transmission and for identifying asymmetry sources. Asymmetric price transmission (APT) occurs when prices are not fully and instantaneously transmitted through the other stages, but differs in speed and/or magnitude in the transmission of prices through the supply chain. APT can alter timing or welfare changes causing market failure and thus set the scene for policy intervention. ATP policy relevance has driven theoretical and empirical research.

Meyer and von Cramon-Taubadel (2004) conducted a review of methods for identifying APT and empirical applications. Apparently, different methods have led to different rejection rates of the symmetry hypothesis and they conclude that there is little rigorous comparison of strengths and weaknesses in the available methods. They point to additional methodological issues that merit further attention like multi-collinearity, data frequency, data anomalies, distinction between statistically and economically significant APT and factors that cause asymmetry. On the latter, Meyer and von CramonTaubadel stress that more emphasis is needed in interpreting possible causes of APT and their relation to structure and institutional features of the market being studied. Frey and Manera (2007) have made a step further in this direction though scrutinising empirical methods for testing a set of classified sources of asymmetry. They have tested results through meta-regression analysis and concluded that asymmetry is frequent in a wide range of econometric models.

Empirical studies have pointed to market structure and the growing concentration of the processing and retail firms as the main reasons for asymmetric price transmission and unequal distribution of welfare along the food chain (Sexton 2000, Vavra et al. 2005). Price transmission analysis identified sources of asymmetries, for example, significant fixed costs, adjustment costs, inventory management and perishable products (Meyer and Cramon-Taubadel, 2004, Vavra et al. 2005, Fernandez and Crespo 2010, Acharya et al. 2011, Felis and Garrido 2015). Other studies underlined the role of agriculture policies in mitigating bargaining power imbalances (Russo et al. 2011, Cacchiarelli Sorrentino 2013, Ciliberti Frascarelli 2013) or looked at the possible role of POs to counterbalance market power exertion (Cacchiarelli Chiavicchioli Sorrentino 2016).

A branch of evidence-based research has focused on understanding how the market functions under imperfect competition. Sexton (2013) and McCorriston (2013) have 
identified factors that may be affecting markets and price developments, other than increasing concentration in processing and retailing sectors. These factors are to be found between vertical-related markets and within stages or with respect to the nature of vertical linkages between stages. They include vertical coordination and control between farming and downstream marketing stages; private labels, quality and differentiation, e.g. geographic location, certified safe and respecting fair-trade practices, consolidations through mergers, acquisitions and unfair practices between firms in different stages leading to unequal rent distribution or practices inflicting consumer harm. An application of the McCorriston et al. (2001) oligopoly model, further developed by Sheldon and Sperling (2006), provides evidence of altered price transmission and consumer surplus distribution along the dairy chain in Italy (Rosa et al. 2015). Using a BLP demand model, Tiboldo et al. (2016) find that national as well as local brands in the fresh milk segment have the lowest own-price elasticity and thus the highest market power. Madau et al. (2016) implement a test proposed by Lloyd et al. (2006) to estimate the presence of buyer power. They notice that a distortive behaviour of retailers and food companies have concurred to enlarge the gap between farmers' and retailers' prices, and call for more research to evaluate buyers' power nature and causes. Bonnet and Zohra (2015), using a model of Draganska et al. (2010), observe that value added created by organic label in the French fluid milk market helped to balance bargaining power along the supply chain. Lianos and Lombardi (2016) use a holistic approach in the Global Value Chain framework. They examine market power and concentration through the vertical links between in the chain to understand if and how lead actors can capture value.

The relevance of price transmission issues along the food chain is due to the potential welfare losses it may entail, notably to weaker actors. Higher concentration in the processing and retail stages makes farmers and consumers the natural candidates.

\section{Policy instruments and market power}

Although policy implementation varies across countries, main features are exemptions from Competition law and special legislation. Improving the performance of markets through promoting farmers' integration in various forms (producer's organisations, cooperatives) are common objectives.

The literature on the interactions of cooperatives and anti-trust policy and their role in improving market performance is extensive. Nash et al. (1996) examine issues in the Australian context focusing on differences in effectiveness across sectors and regions, Youde and Helmberger (1996) analyse anti-trust policies and market power in the USA, focusing on marketing associations. They consider cooperative marketing as desirable in atomistic structures where concentration in procurement is needed to reach economies of scale. Both Youde Helmberger (1996) and Bergman (1997) argue that cooperatives with restrictive membership should be treated as any other type of business. Based on results from an empirical model that includes price discrimination, Bergman (1997) sustains that if cooperatives export a small fraction of their production and the degree of vertical integration is low, the presence of cooperatives may increase social efficiency by mitigating the market power of for-profit firms. On the 
contrary, cooperatives with high market share may discriminate between buyers. In their recent paper, Lianos and Lombardi (2016) acknowledge the different anti-trust policies of the USA and the EU: while cooperatives benefit from anti-trust immunity in the USA, the policy setting in Europe is much more complex and difficult to interpret.

Empirical analysis on the impact of measures aimed at strengthening the bargaining power of farmers in the EU has focused so far on the role of cooperatives, association agreements and vertical integration of farmers in facilitating economies of scale, improving farmers' profit, favouring technology adoption and productivity, etc. Larger POs have been found to be more profitable as they can spread their fixed costs over larger sales volumes and offer better prices as well. Larger POs offer in general also more services to their members than smaller POs, especially when these services are associated with significant investment costs (Van Heck, 2014). This is in line with further evidence in the Italian context, where the use of contracts in the dairy, olive oil and fruit and vegetable sectors have introduced greater transparency in trade relationships between agro-food firms, with positive impacts on the financial management of farmers and food processors (Ciliberti and Frascarelli 2013). Based on a series of studies that compared prices paid between POs and investors-owned firms (IOFs), Van Hecke (2014) has found that average prices are higher in regions with strong cooperative organisations, and that prices paid by IOFs in these regions are higher as well. Bijman et al. (2012) have performed analysis on the dairy sector; they suggest that a strong cooperative presence makes higher prices paid by all dairies in a country. They also find evidence showing that IOFs may pay even a bit more because they focus on specialities, and thus can afford higher prices. The authors have also found a pricevariation-reducing effect of the market share of cooperatives, though this effect was not observed in other sectors under scrutiny (i.e. pig meat). Therefore, participation by POs could ensure a higher income to farmers. Conversely, little evidence exists of higher consumer prices associated with the presence of POs.

Research devoting more policy modelling that accounts for imperfect markets was scarce at the beginning of this century (McCorriston 2002), but a number of application has been developed since then. The work of Russo et al. (2011) highlights that, in presence of market power, benefits from decoupling agriculture support are smaller than under perfect competition (or even negative). They use an approach that relies on shifts in supply, demand or policy to identify and measure market power. Goodhue and Russo (2011) examine the interactions between agriculture policy and market power in the USA flour milling industry. Using a non-parametric approach, they demonstrate that USA wheat millers are able to increase their margins when farmers receive payments through marketing. In other words, market power might allow redistributing benefits from government intervention. Sexton (2013) develops a theoretical model that takes into account vertical coordination, i.e. contracts between farmers and processors in presence of substantial investment costs and product differentiation. He finds that under these conditions buyers matter about the future, and they would pay farmers as much or more than a under a competitive market, but in other settings where vertical coordination is not an issue, the exercise of market power would prevail. Rosa et al. (2015) perform an application of the oligopoly model of McCorriston, further developed by Sheldon, in the Italian dairy chain and found 
that demand elasticity has a modest impact on consumer surplus, but market power and price changes at farm level are the most important determinants of welfare distribution. They conclude that the measures contained in the single CMO may contribute to avoid the unequal margin distribution caused by the growing market asymmetry.

\section{The current EU legislative setting}

The strengthening of the standing of farmers in the agricultural value chain is a declared objective of the European legislator for changes of the CAP legislation (together with other voluntary initiatives) ${ }^{1}$ within the 2013-2020 CAP reform.

In line with this objective, the general exemption to agriculture is maintained in the new CMO Regulation ${ }^{2}$ and sectorial coverage is widened under specific conditions. One prominent feature is the extension of the possibility to recognise horizontal, vertical agreements and inter-branch agreements to all agriculture products covered by the CMO, as well as the extension of the possibility of contractual negotiations (joint negotiation) to olive oil, beef and arable crops. POs, associations of POs and IBOs could receive financial support, under certain conditions, within Rural Development Programmes. ${ }^{3}$ In addition, specific exemptions are defined and dealt on a case-by-case approach (Carrau 2012, Del Cont et al. 2012).

The general derogation to EU competition policy rules continues to apply to the commercial activities of farmers within the framework of the CAP (Article 42 TFEU) and is contained in Art 209 of the new CMO Regulation. However, the practical consequences of this general derogation (as specified in the cited Article) are not clear. As long as this ambiguity is not addressed and clarified, the legal certainty for operators relying on Article $209 \mathrm{CMO}$ is reduced and other, sector-specific derogations in the $\mathrm{CMO}$, may become more relevant.

The horizontal rules on producer cooperation, which include general rules for the recognition and activities of POs, associations of POs and IBOs, are extended to all products covered by the CMO.

Sector-specific provisions in the CMO that authorise joint activities are defined on a case-by-case approach. They include joint selling by producers/POs in certain sectors which go beyond what is permissible under general competition rules for agricultural markets. They are listed below:

1. Standard written contracts in the milk sector. ${ }^{4}$ The joint sale of raw milk by POs was introduced by the so-called milk package ${ }^{5}$ where the price payable for the delivery may be set in a so-called model of written contract. ${ }^{6}$ Unlike the provisions on olive oil, beef and arable crops, the possibility of milk POs to jointly sell (and set prices) for the raw milk of their members is limited only by certain (generous) quantitative thresholds (up to $33 \%$ of national production per PO).

2. Joint selling by POs in the fruit and vegetables sector. As POs and APOs in the fruit and vegetables sector fulfil a particular role, they are granted Union financial assistance in the framework of operational programmes. With a view towards amplifying their effectiveness, POs in fruit and vegetables are required to sell the entire production of their members (with certain exceptions, e.g. for on-farm sale). 
The General Court considered in its decision T-432/2007 that this obligation requires the $\mathrm{PO}$ to be in control of the sale of produce including the setting of the sales price. Thus, the setting of a sale price is a requirement resulting from the producer's organisation's legal obligation to sell its members' production. The activity, in our, and arguably the court's view, is implicitly exempted from competition rules (Velazquez and Buffaria 2015). Some consider a possible systemic weakness of the regime the fact that-unlike collective negotiation possibilities foreseen in the milk, arable crops, olive oil and beef sectors-there is no market share cap on a producer's organisation/APO which intends to engage in joint selling.

3. Contractual relations in the olive oil, beef and veal, and arable crops sectors. These provisions (Articles 169-171 CMO Regulation) are meant to secure possibilities for enhanced cooperation for POs, in addition to what is already permissible under the existing exemptions from competition rules. In other words, the purpose of these Articles is to strengthen the bargaining power of producers, while at the same time avoiding the creation and exertion of market power. Within this objective, the provisions contain safeguards and quantitative thresholds to ensure a level playing field for all operators.

4. Collective negotiations in the sugar sector. The quota system for sugar applies until the end of the 2016/2017 marketing year (Article 124 CMO Regulation). There will no longer be a guaranteed sugar beet price as from that date. The question arises whether growers will be able to continue to collectively negotiate prices with producers after the end of the quota regime, as is the current practice. Unlike in the milk, arable crops, olive oil and beef sectors, there is no explicit collective negotiation provision for sugar beet growers in the CMO. However, the rules for the sugar sector do provide for the collective negotiation of inter-professional agreements between associations of beet growers and sugar manufacturers (so-called agreements within the trade). The legislation has been recently integrated with a Delegated $\mathrm{Act}^{7}$ opening the possibility to introduce a value sharing formula, including market bonuses and loses, being discussed between beet growers and manufacturers during the negotiation process.

A relevant aspect that merits attention is the concept of producer's organisations. In Article 152 of the CMO Regulation, the legislator refers to POs using the same words but referring to different entities.

In paragraph 1 of the $\mathrm{CMO}$, producer's organisations are defined as entities pursuing, among others, the objectives of "ensuring that production is planned and adjusted to demand, particularly in terms of quality and quantity", "concentration of supply and the placing on the market of the products produced by its members..." and "optimising production costs and returns on investments...and stabilising producer prices". Hence, "bargaining" or "governance" might be recognised as producer's organisation according to Article 152.

These activities are also those of POs with a commercial scope, of which cooperatives have historically been the most common example. The same POs activities described in Article 152 paragraphs 1a, 1b and 1c are among the exemptions to competition law included in previous regulations. ${ }^{8}$ For instance, 
the role, legal characteristics and activities of POs were defined in the former fruit and vegetables legislation ${ }^{9}$ and then fully transposed into the CMO Regulation. The French Competition Authority ${ }^{10}$ interpreted derogations in this sector as a substantial exemption to competition rules, based on the economic specificities of the sector. The French Authority explicitly referred to any form of PO, including cooperatives.

On the other side, the 2010 milk package included measures aiming at strengthening the power of milk producers selling to investor-owned firms (IOF). The milk package introduced a new figure also named producer's organisation, which can perform joint selling and collective negotiating contracts with IOFs. But these POs are in governance POs, and as such a different entity with respect to commercial POs.

Both pieces of legislation have been transposed into the $\mathrm{CMO}^{11}$ Regulation, and certain provisions extended to additional sectors (olive oil, beef and veal, and arable crops) in Articles 169 to 171.

In order to help farmers and national competition authorities interpret and apply these provisions, the European Commission has tabled a document containing guidelines for implementation European Commission (2015). The guidelines are also meant to ensure legal consistency across EU member states, as requested by the parliament during the legislative process of the 2013 CAP reform. The guidelines specify conditions POs must comply to benefit from the derogations, including the recognition of $\mathrm{POs}$ and associations of POs, the pursue of specific objectives, the creation of significant efficiencies, relations between the PO, its members and the cap on quantities subject to contractual relations and notifications obligations (see Table 1).

Paradoxically, in the guidelines, the derogation for the joint selling of produce by cooperatives does not appear clearly. The CMO Regulation forbids the charging of identical prices; joint selling may be seen as equating to charging identical prices. Thus, operations by cooperatives could be exempted only under the general competition

Table 1 Conditions for benefiting from rules in Articles 169, 170 and 171 of the CMO Regulation

\begin{tabular}{|c|c|}
\hline Recognition of PO and association of POs & $\begin{array}{l}\text { Needed to benefit the derogation. A PO may be a member of } \\
\text { another PO (second-tier PO) which commercialise the output } \\
\text { by its member PO, and members of the PO can be producers } \\
\text { and other entities which are not producers. }\end{array}$ \\
\hline Pursuing of specific objectives & $\begin{array}{l}\text { At least one of the following: concentrate supply, placing } \\
\text { products of members into the market, optimise production costs. }\end{array}$ \\
\hline Creating significant efficiencies & $\begin{array}{l}\text { Ways: } \\
\text { - by integrating activities in the PO, } \\
\text { - by generating efficiencies and thus } \\
\text { - by contributing to the CAP objectives. } \\
\text { Efficiencies are measured in terms of volume increase or reduction } \\
\text { of costs when the PO carries out at least one activity, or uses } \\
\text { alternative ad hoc methods when the POs carry out various activities. }\end{array}$ \\
\hline $\begin{array}{l}\text { Relations between the } \mathrm{PO} \text { and its } \\
\text { members. }\end{array}$ & $\begin{array}{l}\text { Producers are only members of one PO (but they can sell in parallel } \\
\text { product to the market) and with existing obligations in cooperative } \\
\text { structures. }\end{array}$ \\
\hline $\begin{array}{l}\text { Cap on quantities subject to contractual } \\
\text { relations. }\end{array}$ & $\begin{array}{l}\text { The PO should not hold a dominant position: } \\
\text {-Beef and veal. Maximum 15\% of the total national production of } \\
\text { each product. } \\
\text {-Arable crops. Maximum 15\% of the total national production of } \\
\text { each product. } \\
\text {-Olive oil. Maximum } 20 \% \text { of the relevant market. } \\
\text { Notification obligations. Volume of production to the competent } \\
\text { authorities in the MS. }\end{array}$ \\
\hline
\end{tabular}


rules, if the conditions, i.e. creation of efficiencies, benefits for consumers, no disproportionate restriction of competition, are fulfilled. The exemptions available under general competition rules offer only limited protection for the joint sale of products at a common price, arguably the main purpose of a great number of agricultural cooperatives. It is to note that national competition authorities have not challenged the typical commercial practices of cooperatives as potentially anti-competitive horizontal cooperation among individual producers.

A comparison of the derogations, their nature and the implementation across sectors is contained in Table 2.

\section{Conclusions}

Divergent results emerged from studies on the relation between size and profitability or efficiency, with evidence of significant economies of scale. Larger PO would be more profitable as they can spread their fixed costs over larger sales volumes. In addition, because of this, they could be able to offer better prices. Larger POs may offer more services to their members, especially when these services are associated with significant investment costs. We also expect to find evidence of a positive relationship between participation in the PO and farm income for instance, thanks to higher prices received by farmers participating in POs.

In relation to policy measures aimed at improving the functioning of the food supply chain, the CMO Regulation relies on producer's organisations as the main vehicle for producer cooperation. But the new legislative setting could lead to the paradoxical consequence of impeding the functioning, by challenging the existence and/or creation of POs.

One missing piece in the legislation is the definition of a specific legal form for the recognition of a PO. For instance, cooperatives are among the most common organisational forms of establishment in the agricultural sector, especially in Eastern Member States, but they are not legally referenced.

The case of cooperatives provides a hint of the paradoxical situation that could be faced in the future. Uncertainty, divergent interpretations and difficulties for POs in complying with minimum requirements for exemption may represent a deterrent to the existence/ recognition of POs (Del Cont 2015), and cooperatives in particular. As an example, activities allowed during periods of severe market imbalance (Art. 222 of the CMO Regulation) appear in contradiction with core activities of fruit and vegetable POs (Art. 152). Moreover, the extension of provisions to the olive oil, beef and veal, and certain arable crops has further contributed to terminology confusion of what a POs is.

Widely different conditions apply across sectors without a clear justification. In particular, we refer to three notable differences: (i) joint selling and price setting are allowed in raw milk in the dairy sector; (ii) the possibility for contractual relations is extended to olive oil, beef and veal, and arable crops but under the requirement of fulfilling additional conditions (i.e. generate significant efficiency); (iii) POs in the fruit and vegetable sector are required to sell the entire production of their members, and according to the European Court of Justice (ECJ), this requires the setting of prices.

Derogations on a case-by-case approach lead to legal uncertainty. Exemptions to contractual negotiations, e.g. in the olive oil, beef and veal, and arable crops sectors need to be better qualified, showing consistency with the general exemption to agriculture. For example, in order to integrate certain activities POs must comply with the additional requirement of generating significant efficiencies (the so-called significant efficiency test). 
Table 2 Comparison of derogations

\begin{tabular}{|c|c|c|c|}
\hline & Pre reform & Milk package (2012) & CAP reform 2013-2020 \\
\hline Derogations & $\begin{array}{l}\text { Agreements, decisions and } \\
\text { practises that: } \\
\text {-are part of a national market } \\
\text { organisation; } \\
\text {-are necessary for the } \\
\text { attainment of CAP objectives; } \\
\text {-concern the production, sale } \\
\text { of agricultural products or the } \\
\text { use of joint facilities for the } \\
\text { storage, treatment or } \\
\text { processing. } \\
\text { (TFEU Art } 101 \text { and Art 42, } \\
\text { Regulations } 1184 / 2007 \text {, } \\
\text { 1234/2007, 330/2010, 1218/2010) }\end{array}$ & $\begin{array}{l}\text { In addition to general } \\
\text { derogations: } \\
\text { joint selling of milk and milk } \\
\text { products by POs. } \\
\text { POs can collectively negotiate } \\
\text { contract terms including price } \\
\text { of raw milk. } \\
\text { Deliveries by farmers to their } \\
\text { cooperatives cannot be subject } \\
\text { to joint negotiations, but } \\
\text { collecting cooperatives can } \\
\text { form POs and negotiate } \\
\text { collectively with processors. } \\
\text { (Regulation 261/2012) }\end{array}$ & $\begin{array}{l}\text { Agreements or practises } \\
\text { needed to attain CAP } \\
\text { objectives. } \\
\text { Horizontal, vertical or } \\
\text { inter-branch agreements, } \\
\text { on a case-by-case } \\
\text { approach } \\
\text { (Regulation 1308/2013) }\end{array}$ \\
\hline Conditions & $\begin{array}{l}\text { No price or quota fixing and no } \\
\text { geographical division of markets, } \\
\text { unless CAP objectives are } \\
\text { jeopardised. }\end{array}$ & $\begin{array}{l}\text { Thresholds: volume of milk } \\
\text { negotiated by a PO < 3.5\% } \\
\text { of EU production and }<33 \% \\
\text { national production in MS. }\end{array}$ & $\begin{array}{l}\text { No price or quota fixing, } \\
\text { no geographical division } \\
\text { of markets (with } \\
\text { exceptions). } \\
\text { Market share thresholds }\end{array}$ \\
\hline $\begin{array}{l}\text { Sector } \\
\text { coverage }\end{array}$ & $\begin{array}{l}\text { Hops, olive oil, table olives, } \\
\text { silkworm, tobacco (Reg. 1234-2007); } \\
\text { sugar (Reg. 318/2006); fruit } \\
\text { and vegetables (Reg. 1182/2007); } \\
\text { wine (Reg.479/2008) }\end{array}$ & Milk and milk products & $\begin{array}{l}\text { All agricultural products } \\
\text { covered by Reg. } 1308 / 2013\end{array}$ \\
\hline $\begin{array}{l}\text { Sector } \\
\text { specificities }\end{array}$ & $\begin{array}{l}\text { Tobacco: IBOs provisions could } \\
\text { be extended to non-members, if } \\
\text { they pursue specific objectives. }{ }^{a} \\
\text { Sugar: compulsory delivery } \\
\text { written contracts, where price and } \\
\text { quantities must be defined. } \\
\text { Fruit and vegetables: financial } \\
\text { assistance to POs and APOs. } \\
\text { Market withdrawal by POs } \\
\text { POs are required to sell the entire } \\
\text { production of their members. }\end{array}$ & & $\begin{array}{l}\text { Tobacco: IBOs provisions } \\
\text { could be extended to } \\
\text { non-members if they } \\
\text { pursue specific objectives. } \\
\text { Fruit and vegetables: } \\
\text { financial assistance to POs } \\
\text { and APOs. Market } \\
\text { withdrawal by POs. Joint } \\
\text { selling by POs.c } \\
\text { Dairy: specific written } \\
\text { contracts including prices } \\
\text { (milk package) } \\
\text { Olive oil, beef and veal, } \\
\text { and arable crops: joint } \\
\text { negotiation by POs. } \\
\text { Sugar: collective } \\
\text { negotiation provision not } \\
\text { explicitly mentioned in } \\
\text { Reg. 1308/2013, but rules } \\
\text { for the sugar sector } \\
\text { provide for the collective } \\
\text { negotiation, price and } \\
\text { quantity are part of the } \\
\text { delivery contract(s). }\end{array}$ \\
\hline
\end{tabular}

In particular, pursuing research aiming at finding uses that do not pose threats to public health, improving leaf quality, researching environmentally friendly methods, permitting the use of plant health products

${ }^{b}$ In particular, pursuing research aiming at finding uses that do not pose threats to public health, improving leaf quality, researching environmentally friendly methods, permitting the use of plant health products

'The General Court considered in its decision T-432/2007 that this obligation requires the PO to be in control of the sale

of produce, including the setting of the sales price

Moreover, additional powers for competition authorities were added as safeguards to intervene on a case-by-case basis and to review the relevant product market. ${ }^{12}$

Finally, different judgements or interpretations of legislation could result in solutions that are not in the public interest. For instance, a proactive and well-resourced corporate actor in the value chain can exert results to his advantage vis-à-vis state regulator authorities with divergent goals, sometimes situated across different spatial scales of governance (Wood and Alexander 2016). 
Because of self-assessment, producers and their organisations, as well the national auditing authorities, need positive and clear examples specifying which practises are allowed and under what conditions.

\section{Endnotes}

${ }^{1}$ For example, the high level group on the functioning of the food chain and the food chain initiative.

${ }^{2}$ Regulation (EU) 1308/2013

${ }^{3}$ Regulation (EU) 1305/2013 (Article 209)

${ }^{4}$ Articles 148 and 149 of the CMO Regulation

${ }^{5}$ This package is one of the remedies to tackle the persistent weakness of this market after the abolition of the Quota Regime

${ }^{6}$ Regulation (EU) 261/2012

${ }^{7}$ Commission Delegated Regulation (EU) 2016/1166 of 17 May 2016

${ }^{8}$ Reg.(CE) 26/1962 applying certain rules of competition to production of and trade in agricultural products (Article 2 as regards "production or sale of agricultural products") and Council Reg. 2200/1996 (Art 11)

${ }^{9}$ See the Council Regulation 2200/1996

${ }^{10}$ Opinion No. 08-A-07 of 7 May 2008 on the Common Market Organisation of the fruit and vegetables sector.

${ }^{11}$ See Articles 152, 160 and 161 of the Reg. 1308/2013

${ }^{12}$ Commission Guidelines on the application of specific rules set out in Articles 169, 170 and 171 of the CMO Regulation (2015/C 431/01)

\section{Acknowledgements}

This paper has been selected as the best paper of the 52nd SIDEA Conference in Rome-Viterbo (17-19 September 2015). It has been accepted for publication in this journal following the usual revision process. It reflects the views of the authors and should by no means be associated to those of the European Commission. The authors wish to thank two anonymous referees for their suggestions and comments on an earlier version of the paper.

\section{Author's contributions}

All authors read and approved the final manuscript.

Competing interest

The authors declare that they have no competing interests.

\section{Publisher's Note}

Springer Nature remains neutral with regard to jurisdictional claims in published maps and institutional affiliations.

\section{Author details}

${ }^{1}$ Internal Market, Industry, Competitiveness, and SMEs, European Commission, Brussels, Belgium. ${ }^{2}$ Economics of Agricultural Markets, Agriculture and Rural Development, European Commission, Brussels, Belgium.

Received: 30 June 2016 Accepted: 27 July 2017

Published online: 01 September 2017

\section{References}

Acharya RN, Kinnucan HW, Caudill SB (2011) Asymmetric farm-retail price transmission and market power: a new test. Applied Economics, n 43:4759-4768. Retrieved from http://www.tandfonline.com/doi/abs/10.1080/00036846.2010.498355

Andries A, Garcia Azcarate T (2015) Agriculture, PAC et droit de la concurrence: une vision historique. Revue de I'Union Europeenne, № 585 , Fevrier, pp 83-92

Bergman M (1997) Eur J Law Econ 4:73. doi:10.1023/A:1008683413296

Bijman J, lliopoulos C, Poppe K.J, Gijselinckx C, Hagedorn C, Hanisch M, Hendrikse G, Kühl R, Ollila P, Pyykkönen P, van der Sangen G, External study: "EP pilot project: support for farmers' cooperatives", 2012. https://ec.europa. eu/agriculture/sites/agriculture/files/external-studies/2012/support-farmers-coop/fulltext_en.pdf

Bonnet C, Zohra B-M (2015) Organic label, bargaining power, and profit-sharing in the French fluid milk market. American Journal Agricultural Economics 98(1):113-133. doi:10.1093/ajae/aav047 
Cacchiarelli L, Cavicchioli D, Sorrentino A (2016) Has the force awakened? Producer organizations, supply concentration and buyer power in fruit and vegetable sector, paper prepared for the 153 EAAE meeting, new dimensions of market power and bargaining in the agri-food sector: organisations, policies and models, Gaeta, Italy, June 9-10, 2016

Cacchiarelli L, Sorrentino A (2013) La trasmissione dei prezzi nella filiera pastaria tra fattori congiunturali e riforma della Pac, Agriregionieuropa anno 9 n³5, Dic 2013. Retrieved from https://agriregionieuropa.univpm.it/it/content/article/ 31/35/la-trasmissione-dei-prezzi-nella-filiera-pastaria-tra-fattori-congiunturali-e

Carrau JG (2012) EU competition framework policy and agricultural agreements: collation and comparative analysis of significant decisions at national level. European Parliament Structural and Cohesion Studies, Brussels. Retrieved from http://www.europarl.europa.eu/RegData/etudes/note/join/2012/474547/IPOL-AGRI_ NT(2012)474547_EN.pdf

Carrau JG (2014) Política Agrícola Común y de la Competencia, Revista de Derecho de la Unión Europea, Madrid ISSN 1695-1085, n² 26 - enero-junio 2014, págs. 135-166

Ciliberti S, Frascarelli A (2013) Mandatory rules in contracts of sale of food and agricultural products in Italy: an assessment of Article 62 of Law 27/2012, Paper presented at 104TH EEAE Seminar "Theories an Empirical Applications on Policy and Governance o Agri-food Value Chains", Perugia, Italy, December 13-15, 2013. Retrieved from: https://ideas.repec.org/p/ags/eaa140/163350.htmlf

Del Cont C., Les producteurs agricoles face au marché. Contrats, concurrence et agriculture dans le règlement (UE) n 1308/2013, Revue De Droit Rural-Revue Mensuelle Lexisnexis Jurisclasseur-Octobre 2015

Del Cont C, Bodiguel L, Jannarelli A (2012) EU competition framework: specific rules for the food chain in the new CAP. European Parliament Structural and Cohesion Studies, Brussels. Retrieved from http://www.europarl.europa.eu/ thinktank/en/document.html?reference=IPOL-AGRI_NT(2012)474541

Draganska M, Klapper D, Villas-Boas SB (2010) A larger slice or a larger pie? An empirical investigation of bargaining power in the distribution channel. Mark Sci 29(1):57-74

European Commission (2009) Communication from the Commission to the European Parliament, the Council, the European Economic and Social Committee and the Committee of the Regions. A better functioning food supply chain in Europe COM 2009:591

European Commission (2010) Communication from the commission to the European Parliament, the council, the European economic and social committee and the Committee of the Regions. The CAP towards 2020: meeting the food, natural resources and territorial challenges of the future COM(2010) 672 final

European Commission (2015) Guidelines on the application of the specific rules set out in the specific rules set out in Articles 169, 170 and 171 of the CMO Regulation for the olive oil, Beef and veal an arable crops sectors. Retrieved from http://ec.europa.eu/competition/consultations/2015_cmo_regulation/draft_guidelines\%20_en.pdf

Felis A, Garrido A (2015) Market power and price volatility in markets of fresh fruits and Vegetables, working paper no. 7, ULISSES "understanding and coping with food markets volatility towards more stable world and EU food systems". Retrieved from: http://www.fp7-ulysses.eu/publications/ULYSSES\%20Working\%20Paper\%207_ Market\%20Power\%20Dynamics\%20and\%20Price\%20Volatility\%20in\%20Markets\%

Fernandez-Amador O, Crespo-Cuaresma J (2010) The role of asymmetries in the price transmission mechanism for milk products in Austria, University of Innsbruck, Working Papers in Economics and Statistics, 2010-21. Retrieved from https://ideas.repec.org/p/wfo/wpaper/y2010i378.html

Frey G, Manera M (2007) Econometric models of asymmetric price transmission. Journal of Econometric Surveys, Volume 21, Issue 2, April 2007, pp 349-415

Goodhue R, Russo C (2011) Modelling processor market power and the incidence of agricultural policy: a non-parametric approach, National Buereau of Economic research, Working Paper 16706, January 2011. Retrieved from http://www.nber.org/chapters/c12106.pdf

Khemani RS, Shapiro DM (1993) Glossary of industrial organisation economics and competition law. OECD Retrieved from http://www.oecd.org/regreform/sectors/2376087.pdf

Kirkwood JB (2005) Buyer power and exclusionary conduct: should Brooke Group set the standards for buyer-induced price discrimination and predatory bidding? Antitrust Law Journal 72:625

Lianos I, Lombardi C (2016) Superior bargaining power and the global food value chain: The wuthering heights of holistic competition law? Competition law and policy and the food value chai, On-Topic, Concurrences no. 1-2016 Available at https://papers.ssrn.com/sol3/papers.cfm?abstract_id=2773455

Lloyd T, McCorriston S, Morgan W, Rayner T, Weldegebreil H (2006) Market power in UK food retailing: theory and evidence from seven product groups, paper presented at the International Association of Agricultural Economists Conference, Gold Coast, 12-18 August. Available at http://ageconsearch.umn.edu/bitstream/25712/1/cp060310.pdf

Madau FA, Furesi R, Pulina P, (2016) The existence of buyer power in the Italian fresh milk supply chain, Br Food J, Vol. 118 Iss 1 pp. 70 - 82 doi:10.1108/BFJ-12-2014-0395

McCorriston S (2002) Why should imperfect competition matter to agricultural economists? European Review of Agriculture Economics 29(3):349-371

McCorriston S (2013) Competition in the food chain. Working paper no. 11 TRANSFOP transparency of food pricing. Retrieved from: http://www.transfop.eu/media/universityofexeter/businessschool/documents/centres/transfop/ Competition_in_the_Food_Chain.pdf

McCorriston S, Morgan CW, Rayner AJ (2001) Price transmission: the interaction between market power and returns to scale, European Review of Agricultural Economics. Vol 28(2):143-159

Meyer J, Cramon-Taubadel S (2004) Asymmetric price transmission: a survey. J Agric Econ 55(3):581-611

Nash J, Fagan M, Davenport S (1996) Some issues in the application of competition policy to agriculture. Paper presented at the 41 st Annual Conference of the Australian Agricultural and Resource Economics Society

Oecd (2009) Monopsony and buyer power, OECD policy roundtable series, DAF/COMP(2008)38

Rosa F, Weaver RD, Vasciaveo M (2015) Structural changes and dairy chain efficiency in Italy, Internation. Journal of Food System Dynamics 6 (3), 2015, 191-211 http://ageconsearch.umn.edu/record/245113

Russo C, Goodhue RE, Sexton RJ (2011) Agricultural support policies in imperfectly competitive markets: why market power matters in policy design. Am J Agric Econ 93(September 2011):1328-1340 
Sexton R (2000) Industrialization and consolidation in the U.S. food sector: implications for competition and welfare, American Journal of Agriculture Economics, 82(5) (Number 5, 2000): 1087-1104

Sexton R (2013) Market power, misconceptions, and modern agricultural markets. Am J Agric Econ 95(2013):209-219 Sheldon I, Sperling A (2006) Market structure, industrial concentration and price transmission. Paper presented at the workshop on "market integration and vertical ans spatial price transmission in agricultural markets", University of Kentucky, Lexington, KY. April 21, 2006

Sorrentino A, Russo C, Cacchiarelli L (2016) Market power vs. bargaining power models: implications for policy analysis. Paper prepared for the 153 EAAE meeting, new dimensions of market power and bargaining in the agri-food sectororganisations, policies and models, Gaeta, Italy, June 9-10, 2016

Tiboldo G, Lopez R, Hirschb S (2016) Private label market power: evidence from Italian dairy retailing, selected paper prepared for presentation at the 2016 Agricultural \& Applied Economics Association Annual Meeting, Boston, Massachusetts, July 31-August 2 2016. Retrieved from: http://ageconsearch.umn.edu/record/235592/files/aaea_ fullpaper_blp.pdf

Tothova M, Velazquez B (2012) Issues and policy solutions to commodity price volatility in the European Union. Paper presented to the 2nd IFAMA Annual Symposium "The Road to 2050. The China Factor", Shanghai, June 2012

Van Heck K (2014) Assessing efficiencies generated by Agricultural Producer Organisations. European Commission, 2014. Retrieved from http://ec.europa.eu/competition/publications/agricultural_producers_organisations_en.pdf

Vavra P, Goodwin BK, ELC CJ (2005) Analysis of price transmission along the food chain. OECD Food, Agriculture and Fisheries Working Papers 3:58

Wood S, Alexander A (2016) Regulation in practice: power, resources and context at the local scale in UK food retailing. Environ Plan A 48:1848-1863 first published on May 19, 2016

Youde JG, Helmberger PG (1996) Marketing cooperatives in the U.S.: membership policies, market power, and antitrust policy. J Farm Econ 48(3): 23-36. Part 2: Effective Competition and Changing Patterns in the Marketing of Agricultural Products (Aug., 1966)

Submit your manuscript to a SpringerOpen ${ }^{\circ}$ journal and benefit from:

- Convenient online submission

- Rigorous peer review

Open access: articles freely available online

- High visibility within the field

Retaining the copyright to your article 